\title{
Teacher Creativity and School Climate
}

\author{
$1^{\text {st }}$ Hetreda Terry \\ History Education Department \\ Fakulty of Social Science, Universitas \\ Negeri Manado \\ Manado, North Sulawesi \\ hetredaterry@unima.ac.id \\ $4^{\text {th }}$ Yohanes Burdam \\ History Education Department \\ Faculty of Social Science \\ Universitas Negeri Manado \\ Manado, Indonesia \\ yohanesburdam@unima.ac.id
}

\author{
$2^{\text {nd }}$ Ruth Sriana Umbase \\ History Education Department \\ Faculty of Social Science \\ Universitas Negeri Manado \\ Manado, Indonesia \\ ruthumbase@unima.ac.id \\ $5^{\text {th }}$ Aksilas Dasfordate \\ History Education Department \\ Faculty of Social Science \\ Universitas Negeri Manado \\ Tondano, Indonesia \\ aksilas.unima@gmail.com
}

\author{
$3^{\text {rd }}$ Aldegonda Evangeline Pelealu \\ History Education Department \\ Faculty of Social Science \\ Universitas Negeri Manado \\ Manado, North Sulawesi \\ aldegonda_pelealu@unima.ac.id
}

\begin{abstract}
This research was held in several Senior High School in the North Sulawesi Province. The teacher creativity playing the important role in order to create the goal in teaching efforts at schools, because the teachers not just teach but acknowledge the student as well. Based on that, every teacher had to having their own creativity to enroll their duty as a professional educator. School climate being one of the factors which is affected the creativity of the teacher. Aimed of this research was to know the description about the influence of school organization climate to teacher creativity, used survey method and quantitative approach. Therefore, to collected the data was using instrument such as a questionnaire with Likert scale. The result was showed that there is positive influence between school organization climate and teacher creativity with coefficient value 0,183 and $t$-value $2,151>$ value of table. Teacher creativity being the most important parts of teaching activity even more could be the entrance to improving the target result of the student in learning. The good and conducive school climate while running the duty could create better inter action to be more educative and effective, hand in hand with good school organization climate would give the room for creativity and innovation to encourage the teacher to become more creative and innovative.
\end{abstract}

\section{Keywords-Teacher Creativity, School Climate}

\section{INTRODUCTION}

To develop the quality of education it is really depend on idea and the creativity from related people; national level, region and school. A half result from educational system is still lack in national scale or school. It is not depend to the teacher's teaching ability but occur by lack of creativity in learning process.

To develop idea and teacher creativity being the main point to reach out the good quality of education. By creativity, teacher can create new method of effective and dynamic learning process which can make students more enjoy able. Teacher's creativity related to design and preparing the materials, manage the class by using variative method and strategy to develop the instrument. Those creativities should be understanding bye the teachers especially the goal and result that will be expected [1].

To create the good quality of education is not easy as we thought. It depends on some components as well as teacher's ability. It is important to build up the quality of education start from the teacher. It the terms of battle, teachers are the front line in the war to determine will be win or lose the battle. The Presence of teacher as the top of the spear of success, education should be known as personal calling not as teacher's obligation.

Teacher is a profession who directly keep in touch with human related to their need to develop for being mature by learning process. Learning process by the teacher to the students is effective, interactive and cognitive. Besides, teacher has a role as determiner of success in organization because they directly interacted with the students to be graduated as expected. The creativity of the teacher should be optimal. The teacher had important role and should has high motivation.

Teacher has a responsibility to enrich the goal target in school. Teacher's responsibility is not only about teaching, but to educate which are sharing the knowledge, culture and togetherness. It means that the teacher should has creativity to be professional on the job.

Creativity related to self confidence, without self confidence somebody will not think creatively, and will always worries about many things. Self confidence means able to transfer what we know and practice. Self confidence comes when we decided to do something. Self confidence is not necessary because we are smart but by realizing to learn and do something better. It means that self confidence comes when we had a big desire to make a change.

Besides, the creative teacher should have ability and know how to do innovative and creative learning process in a class to enrich the target. The teacher should able to encourage and find out the best way to push and develop their achievement [2]. Teacher competence is ability to manage the class. The main point is teacher ability in learning process (learning what to be learnt), but teacher should able to create and using positive situation to bring students and develop their competence. With teacher competence useful for students to develop their professional ability. It means that in globalization era we need the teacher who smart, creative, and have a big desire empowering the people.

In facts, many of teachers' creativity are low. Which is not maximum. Besides, teaching and learning 
process are passive, less of interest, less of motivation, less of suitable time, less of students' interaction, less of innovative method which is finally impacted to the unsuccessful result. Those point indicated that teacher less of optimal and creative in learning process.

Good school climate impacted the good space and creative time to the teacher doing the obligation until the goal of education rich out. If the school climate unsustainable it causes contrary to the teacher.

Is the school climate impact to teacher's creativity? The aim of this research is to describe the influence of school climate to teacher's creativity.

\section{RESEARCH METHODS}

In conducting this research used survey method approach by quantitative correlation technique. By using correlation technique will impact to the result of related variation with other variation coefficient. To collect the data using questionnaire. The list of question according to the researcher variable which are: (1) teacher creativity measured by questionnaire filling out by the principal. (2) school climate measured the teachers as respondent. The questionnaire is a list a question given to the responded to the result. (3) The total population is 525 people. The sample taken is 84 responded from 9 Senior High School in Manado, North Sulawesi. The questionnaire has been filled san submitted to next step of analysis.

\section{RESULTS AND DISCUSSION}

The result of this research showed that School Climate has positive impact through teacher's creativity. It is showed by data hypothesis examination that that School Climate has positive impact through teacher's creativity with coefficient impact 0,183 and $t$ count is $2,151>$ grade $t$ table is 1,66 . These data showed if school climate is stable can impact to increase teacher's creativity.

This research is parallel with Putri's researc, stated that correlation between Work Climate and Creativity in SD Negeri District Tanjung Harapan Solo categorized good. It means that work climate at the school contribute impact significantly toward teacher' creativity. Then Putri stated by creating work climate to stable will make teacher's creativity improve [3].

One of important part from school climate is teacher's spirit of work. Reference [4] stated work spirit variable and creativity have positive correlation which is positive and significant means that when someone work spirit is high teacher' creativity will be high as well.

Good and stable school climate will be impacted to effective, educative and good interaction, also school climate can give good space for teacher's creativity and innovation to reach the goal of education. On the contrary, will be happened if school climate doesn't stable for a teacher [5]. Reference [6] stated that good organization is organization which support development of creativity. In other side, reference [7] describes that school is social organization which designed to obtain education activities for enrich the goal.

Good and stable school climate will create educative and creative interaction, also school climate can give space to teacher's creativity and innovation to enrich the goal of education [8]. On the contrary, will be happened if school climate doesn't stable for a teacher.

The importance of principal, teachers, and staff to take care of school climate in organization as the picture of the goal of organization. The goal of organization determining by school management as school climate creator to encourage stable situation.

In creating stable situation principal should taking care about school leadership. Similarly, stated by reference [9] in her research stated that there is a positive impact and significant between principal leadership and school climate toward effective school.

Effective and efficient school development encourage by some variable related to education system which is included school climate. School climate change has to do as a quick response of low quality of education. This is supported by basic change of several life aspect which asking for education adaption and school climate to be stabled to support learning system. Stable Culture and School climate are important to help students enjoy and stay positive toward the teachers, parents and society to be received. This thing will be happened through habit, positive role, relation and team work by respect each other [10].

Condition of work area at school showed the school climate that will be impacted teacher's creativity doing their job. Through teacher's creativity learning process in class will be more effective and fun as model of impacted learning system to students' lifestyle. Teacher' creativity is important thing in learning process as the window to increase students study result.

Teacher's creativity and School Climate can create teacher's professionality then impact to the result. In this case the goal of learning process. Dewi stated that teacher professionality and school climate have impacted effective grade to $83,8 \%$. It is recommended to the teachers increase their professionality through creativity development while the school can build good school climate through habit and culture by school staff [11].

The quality of education sustains when the process of education united and the role of teacher as the first thing to create the perception that school climate influenced learning process. It means, teacher perception of work area in school will show how school climate impact teacher's work. Through teacher's creativity in class will create fun activities to impacted students learning result in life. Teacher's creativity is important thing in learning process as the door in way to increase students learning result.

\section{CONCLUSION}

After conducting this research, it can be concluded that School Climate has positive impact towards teacher's creativity. It means that if school climate is conductive school climate will increase teacher' creativity.

\section{ACKNOWLEDGMENT}

We would like to say thanks to the Rector of Manado State University who has facilitated the research and writing of this article, also to our fellow research team and writers. Thanks also to the Committee of International Conference on Social Science (ICSS) and the Atlantis Press Publisher which has facilitated the publication of this article. 


\section{REFERENCES}

[1] H. A. R. Tilaar, Pengembangan sumber daya manusia dalam era globalisasi: visi, misi, dan program aksi pendidikan dan pelatihan menuju 2020. Gramedia Widiasarana Indonesia, 1997.

[2] S. Amri and I. K. Ahmadi, Proses Pembelajaran Inovatif dan Kreatif dalam Kelas. 2010.

[3] A. P. Putri, "Kontribusi Iklim Kerja Terhadap Kreativitas Guru Sekolah Dasar Negeri Kecamatan Tanjung harapan Kota Solok," J. Bahana Manaj. Pendidik., vol. 3, no. 1, pp. 739-747, 2015.

[4] N. Yuliani and N. T. Pratitis, "Minat pada Profesi Guru, Semangat Kerja dan Kreativitas Guru Taman Kanak-Kanak," $J$. Psikol. Tabularasa, vol. 8, no. 1, 2013.

[5] S. Setuju, "Analisis Kreativitas Guru Dalam Pembelajaran Menggunakan Alat Ukur (MAU) Keahlian Teknik Permesinan Di Kabupaten Sleman Pada Tahun Ajaran 2012/2013," J. Taman Vokasi, vol. 1, no. 1, 2017.
[6] D. Meirawan, "Kepemimpinan \& Manajemen Pendidikan Masa Depan," 2010.

[7] Mulyono, Manajemen Administrasi dan Organisasi Pendidikan. Yogyakarta: Al-Ruzz Media, 2008.

[8] U. Suharsaputra, Administrasi pendidikan. Bandung: Rafika Aditama, 2010.

[9] M. Mutmainah, "Perilaku Kepemimpinan, Iklim Sekolah Dan Sekolah Efektif," J. Adm. Pendidik. UPI, vol. 24, no. 1, pp. 163$172,2017$.

[10] P. F. Dewi, "Pengaruh Guru Profesional dan Iklim Sekolah Terhadap Mutu Pembelajaran SD Muhammadiyah Terpadu Ponorogo," Muslim Herit., vol. 2, no. 2, pp. 369-388, 2018.

[11] L. Zahro, "Urgensi Pembinan Iklim Dan Budaya Sekolah," J. Pendidik. Agama Islam (Journal Islam. Educ. Stud., vol. 3, no. 1, pp. 157-186, 2016. 